\title{
MODELS FOR PREDICTING COMPRESSIVE STRENGTH AND WATER ABSORPTION OF LATERITE-QUARRY DUST CEMENT BLOCK USING MIXTURE EXPERIMENT
}

\author{
F. 0. Okafor ${ }^{1}$ and E. A. Egbe ${ }^{2, *}$ \\ 1 DePartment of Civil ENGineERING, University of NigERIA, NSUKKA. ENUGU STATE, NIGERIA. \\ 2 Cross River State Community and Social Development Agency, Calabar, Cross River State, Nigeria \\ E-mail addresses: ${ }^{1}$ fidelis.okafor@unn.edu.ng, ${ }^{2}$ egbesonandy@yahoo.com
}

\begin{abstract}
The use of laterite, quarry dust and recycle aggregates etc as replacement for sand in sandcrete block production is common trend in developing countries like Nigeria. Most resources and research efforts are committed towards conducting trial test with a view to coming up with mix production that will yield the desired property. This work presents a mathematical model for predicting the compressive strength and water absorption of laterite-quarry dust cement block using augmented Scheffe's simplex lattice design. The statistical models developed can predict the mix proportion that will yield the desired property. The models were tested for lack of fit and found to be adequate.
\end{abstract}

Keywords: compressive strength, laterite, mixture experiment, quarry dust, water absorption

\section{INTRODUCTION}

Sandcrete blocks are extensively used in construction of buildings and other structures for the service of man. Being a very important construction material, it is expedient that its quality and durability be of paramount concern to designers, builders, and other users of structures made with them. As the demand for natural sand continue to increase on daily basis, arising from the building and construction of new infrastructure and expansion of existing ones, the construction industries of most developing countries are compelled to identify alternative materials in order to lessen or eliminate the demand for natural sand. Laterite and quarry dust are some of the materials that have been identified as suitable alternatives and are now being used either partially or wholly in block production. Their consideration as alternatives to natural sand is informed by the fact that natural sand mining on either side of the rivers, upstream or in-stream is one of the causes of environmental degradation and also a threat to biodiversity. The alarming rate of unrestricted sand mining which damages the ecosystem of natural habitants of organisms living on the riverbeds, affects fish breeding and migration, spells disaster for the conservation of many birds species and increases saline water in the rivers [1]. Further, the demand for sand for construction according to Asiedu et al [2], has led to continuous increase in the cost of construction. Hence utilizing laterite and quarry dust either partially or wholly as substitutes for natural sand in the production of sandcrete blocks can significantly bring down the cost of construction.

Recently, in most major cities across Nigeria, manufacturers of sandcrete blocks have resorted to utilizing a combination of quarry dust and laterite to replace natural sand, and at other occasions, a combination of natural sand, laterite and quarry dust for the production of sandcrete blocks used in the construction of buildings and structures. Producers of sandcrete blocks that utilize these materials use arbitrary mixes and the strength of blocks produced using this combination of quarry dust and lateritic sand as replacement for natural sand cannot be guaranteed. The appropriate mix of laterite and quarry dust or the three is not known. Drawing from the forgoing therefore, the study addresses these gaps and concerns raised.

While the effect of separate inclusion of laterite and quarry dust in sandcrete blocks has been addressed and documented by several researchers, [3, 4], works that combine laterite and quarry dust in sandcrete blocks or concrete are few. One of such work was that by [5] and [6] that utilizes a blend of quarry dust and laterite as full replacement in concrete. The study gave the proportion of $25 \%$ laterite and $75 \%$ quarry dust as optimum in concrete. There is also lack of appreciation for the role of water in the mix. Most often, as also found in some documented researches, water is added based on 
discretion. This has made replication of such works difficult.

Moreover, there exist no models that predict the strength and other properties of sandcrete blocks made with laterite and quarry dust blend as full replacement for natural sand. The importance of such models cannot be over-emphasized, as they will help in mix proportioning and cater for cost always associated with laborious laboratory trial mixes. The uniqueness of this study is that, while other studies have focused on separate inclusion of quarry dust and laterite in block as partial or full replacement for natural sand, this study investigated the use of laterite and quarry dust blend as full replacement to natural sand in the production building blocks.

\section{MIXTURE EXPERIMENT AND SCHEFFE'S EQUATIONS}

Mixture experiments are a special class of response surface experiments where the product under investigation is made up of several components or ingredients. In this instance, the response is a function of the proportions of the different ingredients in the mixture.

Cornel [7] describes a mixture experiment as "that which the response is assumed to be dependent on relative proportions of the constituent materials and not on their total amount." The two basic requirements that must be fulfilled for such experiments are: the sum of the proportions of the constituents must add up to 1 and that none of the constituents will have a negative value. These requirements are represented mathematically as thus:

$$
\begin{aligned}
& X_{1}+X_{2}+\cdots+X_{q}=\sum_{I=1}^{q} X_{i}=1 \\
& 0 \leq X_{i} \leq 1
\end{aligned}
$$

In (1) and (2), $q$ is the number of mixture components. and $X_{i}(i=1$ to $q)$ is the volume or mass proportion of component $i$ in the mixture.

It should be noted that since the total proportions of the constituents is constrained to 1 , only $q-1$ of the variables or constituents can be independently chosen.

A lot of mixture experiment model have been formulated by researchers. One of such model which is most popular is the Scheffe's simplex lattice design. The canonical form of the Scheffe's [8] polynomial equations for second degree is reproduced in the form below:

$$
\hat{\mathrm{y}}=\sum_{1 \leq i \leq q} \beta_{i} X_{i}+\sum_{1 \leq i \leq j \leq q} \beta_{i j} X_{i} X_{j}
$$

In (3), $\hat{\mathrm{y}}$ is the response function and $\mathcal{X i}(\mathrm{i}=1$ to $\mathrm{q})$ is the proportion of component in the mixture. The second degree polynomial is the most commonly used polynomial to fitting mixture experiment data. For a four component mixture, canonical equation can be given as:

$$
\begin{aligned}
\hat{\mathrm{y}}=\beta_{1} X_{1}+\beta_{2} X_{2} & +\beta_{3} X_{3}+\beta_{4} X_{4}+\beta_{12} X_{1} X_{2}+\beta_{13} X_{1} X_{3} \\
& +\beta_{14} X_{1} X_{4}+\beta_{23} X_{2} X_{3}+\beta_{24} X_{2} X_{4} \\
& +\beta_{34} X_{3}
\end{aligned}
$$

The estimated coefficients in canonical equation are obtained from a regression analysis of the mixture experimental data. The canonical polynomial has fewer terms than the standard polynomial and is often referred to as the $\{q, m\}$ polynomial; $m$ being the degree of the polynomial

Mixture models have been formulated and applied in many real life situations to solve problems in fields such as Medicine, Pharmacy, Food industry, agriculture and engineering. Osadebe et al [9] formulated a mathematical model for optimization of compressive strength of sandlaterite blocks using Osadebe regression method. Other forms of mixture models that have been formulated as regards sandcrete blocks and concrete are [10 - 22].

\subsection{Materials and Methods}

The materials used for this work are:

Cement: Ordinary Portland cement, grade $32.5 \mathrm{~N}$ obtained from a major dealer in Calabar conforming to BS 12 was used for all the tests.

Water: Potable pipe born water supplied by the Cross River State Water Board (CRSWB) limited was used for both specimen preparations and curing.

Laterite: Laterite was obtained from a borrow pit site at Akim- Akim in Odukpani Local Government area of Cross River State. The specific gravity of the laterite was 2.56 .

Quarry dust: Quarry dust was obtained from the abundant deposits at Akamkpa quarry site in Akamkpa Local Government area of Cross River State, a few minutes drive from Calabar metropolis. The quarry dust had a specific gravity of 2.52 .

\subsection{Exprimental design}

Minitab 16 [23], a statistical software was used in designing the experiment using an augmented $\{4,2\}$ schefee's simplex lattice design. The design simplex is shown in Figure 1 whereas the design matrix of the augmented $\{4,2\}$ simplex is shown in Table 1 . The design contains ten mixes at the vertices and edge of the tetrahedron, augmented with five more mixes within the simplex. These five points were used as check points to validate the models developed. There were also replicate points at the vertices and centriod of the tetrahedron, making it a total of twenty points. The design was based on pseudo component and randomization was applied.

\subsubsection{Components Transformation and Moulding of the Blocks}

The pseudo ratio was transformed to real component ratios used for the moulding of the blocks. The 
relationship between the real component ratios and the pseudo components is as indicated below:

$$
R=A P
$$

In (6), $R$ is a vector containing the real ratios of the components, $P$ is a vector containing the pseudo ratios and $A$ is a transformation matrix which can be obtained from trial mixes given as:

$$
A=\left(\begin{array}{cccc}
0.53 & 0.63 & 0.80 & 0.9 \\
1 & 1 & 1 & 1 \\
5.4 & 3 & 9 & 5 \\
0.6 & 3 & 1 & 5
\end{array}\right)
$$

The element of each column of [A] represents the components proportions at the vertex in the following order Water $\left(\mathrm{X}_{1}\right)$, cement $\left(\mathrm{X}_{2}\right)$, quarry $\operatorname{dust}\left(\mathrm{X}_{3}\right)$ and Laterite $\left(\mathrm{X}_{4}\right)$.

A total of one hundred and twenty (120) hollow blocks, $450 \mathrm{~mm} \times 225 \mathrm{~mm} \times 225 \mathrm{~mm}$ overall dimensions, were moulded using a Vibrating block moulding machine. The surface area of the solid portion of the blocks is $56250 \mathrm{~mm}^{2}$, representing approximately $55 \%$ of the overall surface area of the block. The aggregates were used in their dry condition and batching was by weight. Manual mixing was employed. The blocks were cured in open air for 28 days by sprinkling them with water, twice daily. Sixty blocks each (three for each run) were used to determine the compressive strength and water absorption. The remaining 20 were for contingencies.

\subsubsection{Compressive Strength and Water absorption}

The compressive strength of a block is possibly one of the most important strength properties used to judge the overall quality of the block. The compressive strength is also helpful in determining other properties of block with few exceptions. It was determined by BS [24] where the hardened block, after appropriate curing (28 days), is subjected to increasing compressive load until it failed by crushing, and determining the crushing force. Mathematically, it is given as:

$$
f c=F / A
$$

In (7), $f c$ is the Compressive Strength, $F$ is the Crushing load and $A$ is the Cross sectional area of the test specimen.

Water absorption was carried out in accordance with the requirement of [25]. It is expressed as the difference between the weight before and after immersion, expressed as a percentage of the dry weight. Mathematically, the water absorption is given as:

$$
W_{a}=\frac{W_{d}-W_{s}}{W_{d}} \times 100 \%
$$

Here, $W_{a}$ is the Water absorption, $W_{d}$ is the Dry weight of block, and $\mathrm{W}_{s}$ is the Weight of block after soaking in water for 24 hours

\section{RESULTS AND DISCUSSIONS}

The pseudo components, actual mix ratios and the response from compressive strength and water absorption tests are shown in Table 1.

\subsection{Model Development for Compressive Strength}

The second degree model (equation (1) ), was fitted to the data set of the 20 compressive test responses at $95 \%$ confidence limit $(\alpha=0.05)$ using[23]. The parameter estimate of the coefficients and analysis of variance tables are shown in table 2 and 3 respectively, while the normal probability plot of the residual is shown in Fig 2. The model for compressive strength is therefore:

$$
\begin{aligned}
\hat{\mathrm{y}}=2.4489 X_{1}+ & 1.8797 X_{2}+1.8500 X_{3}+2.1997 X_{4} \\
& +1.1162 X_{1} X_{2}+0.4207 X_{1} X_{3} \\
& +0.2791 X_{1} X_{4}+2.7656 X_{2} X_{3} \\
& +1.4236 X_{2} X_{4}+0.3256 X_{3} X_{4}
\end{aligned}
$$

The $p$-value for lack-of-fit being 0.729 which is greater than $\alpha$ (0.05). The normal probability plot of the residual in Figure 2, reveals that the residuals fall reasonably close to the reference line, with a $p$-value of 0.151 ( $>$ $0.05)$, indicating that the data follow a normal distribution, hence justifying the assumption required for use of analysis of variance. The inference drawn from here is that, equation (9) is adequate for predicting the $28^{\text {th }}$ day strength of laterite-quarry dust blocks.

Model for Water Absorption

Again using the data in Table 1 a model equation for water absorption is given as:

$$
\begin{aligned}
\hat{y}=8.55 X_{1}+5.41 & X_{2}+7.58 X_{3}+7.50 X_{4}-0.64 X_{1} X_{2} \\
& -12.96 X_{1} X_{3}-5.70 X_{1} X_{4}+4.45 X_{2} X_{3} \\
& +7.16 X_{2} X_{4}-0.33 X_{3} X_{4}
\end{aligned}
$$

The model shows that there is insignificant lack-of-fit, the $p$-value for lack-of-fit being 0.855 which is greater than 0.05 and therefore adequate for predicting the $28^{\text {th }}$ day Water absorption of laterite-quarry dust blocks. The normal probability plot of the residuals is shown in Figure 3. It shows that the points fall reasonably close to the reference line and follows a normal distribution with a $p$-value of $0.054(>0.05)$.

\section{CONCLUSION AND RECOMMENDATION}

Mathematical models for predicting the compressive strength and water absorption of laterite-quarry dust cement blocks were developed in this work. The models can be used to predict the compressive strength of blocks ranging from 1.81 to $2.56 \mathrm{~N} / \mathrm{mm}^{2}$. The use of these models will greatly help Nigerian block producers to meet the minimum Nigerian Industrial Standard, [26] recommended values for compressive strength and water absorption. The models also help in reducing the time and energy usually wasted in trial mix. 
Table 1: The pseudo components, actual mix ratios and the responses from compressive strength and water absorptions

\begin{tabular}{|c|c|c|c|c|c|c|c|c|c|c|c|}
\hline \multirow[b]{2}{*}{$\begin{array}{l}\text { Run } \\
\text { Order }\end{array}$} & \multirow[b]{2}{*}{$\begin{array}{l}\text { Std } \\
\text { Order }\end{array}$} & \multicolumn{4}{|c|}{ Pseudo Component } & \multicolumn{4}{|c|}{ Actual mix ratio } & \multicolumn{2}{|c|}{ Responses } \\
\hline & & $\begin{array}{l}\text { Water } \\
\text { (X1) }\end{array}$ & $\begin{array}{l}\text { Cement } \\
\text { (X2) }\end{array}$ & $\begin{array}{c}\text { Quarry } \\
\text { dust (X3) }\end{array}$ & $\begin{array}{c}\text { Laterite } \\
\text { (X4) }\end{array}$ & $\begin{array}{c}\text { Water } \\
\text { (X1) }\end{array}$ & $\begin{array}{c}\text { Cement } \\
(\mathrm{X} 2)\end{array}$ & $\begin{array}{c}\text { Quarry } \\
\text { dust (X3) }\end{array}$ & $\begin{array}{c}\text { Laterite } \\
\text { (X4) }\end{array}$ & $\begin{array}{c}\mathrm{Y}_{c}(\mathrm{Nmm}- \\
2\end{array}$ & $Y(w \%)$ \\
\hline 1 & 5 & 0 & 1 & 0 & 0 & 0.63 & 1 & 3 & 3 & 1.87 & 5.52 \\
\hline 2 & 11 & 0.25 & 0.25 & 0.25 & 0.25 & 0.72 & 1 & 5.6 & 2.4 & 2.56 & 5.87 \\
\hline 3 & 16 & 1 & 0 & 0 & 0 & 0.54 & 1 & 5.4 & 0.6 & 2.5 & 8.09 \\
\hline 4 & 3 & 0.5 & 0 & 0.5 & 0 & 0.67 & 1 & 7.2 & 0.8 & 2.24 & 5.06 \\
\hline 5 & 7 & 0 & 0.5 & 0 & 0.5 & 0.77 & 1 & 4 & 4 & 2.37 & 8.4 \\
\hline 6 & 4 & 0.5 & 0 & 0 & 0.5 & 0.72 & 1 & 5.2 & 2.8 & 2.37 & 6.9 \\
\hline 7 & 8 & 0 & 0 & 1 & 0 & 0.8 & 1 & 9 & 1 & 1.81 & 6.35 \\
\hline 8 & 15 & 0.125 & 0.125 & 0.125 & 0.625 & 0.81 & 1 & 5.3 & 3.7 & 2.42 & 7.2 \\
\hline 9 & 2 & 0.5 & 0.5 & 0 & 0 & 0.585 & 1 & 4.2 & 1.8 & 2.56 & 7.02 \\
\hline 10 & 9 & 0 & 0 & 0.5 & 0.5 & 0.85 & 1 & 7 & 3 & 2.09 & 7.65 \\
\hline 11 & 17 & 0 & 1 & 0 & 0 & 0.63 & 1 & 3 & 3 & 1.89 & 5.13 \\
\hline 12 & 10 & 0 & 0 & 0 & 1 & 0.9 & 1 & 5 & 5 & 2.2 & 7.74 \\
\hline 13 & 1 & 1 & 0 & 0 & 0 & 0.54 & 1 & 5.4 & 0.6 & 2.45 & 8.99 \\
\hline 14 & 6 & 0 & 0.5 & 0.5 & 0 & 0.72 & 1 & 6 & 2 & 2.54 & 7.7 \\
\hline 15 & 19 & 0 & 0 & 0 & 1 & 0.9 & 1 & 5 & 5 & 2.2 & 7.2 \\
\hline 16 & 12 & 0.625 & 0.125 & 0.125 & 0.125 & 0.63 & 1 & 5.5 & 1.5 & 2.56 & 6.26 \\
\hline 17 & 18 & 0 & 0 & 1 & 0 & 0.8 & 1 & 9 & 1 & 1.9 & 8.18 \\
\hline 18 & 20 & 0.25 & 0.25 & 0.25 & 0.25 & 0.72 & 1 & 5.6 & 2.4 & 2.49 & 6.91 \\
\hline 19 & 13 & 0.125 & 0.625 & 0.125 & 0.125 & 0.674 & 1 & 4.3 & 2.7 & 2.5 & 7.15 \\
\hline 20 & 14 & 0.125 & 0.125 & 0.625 & 0.125 & 0.76 & 1 & 7.3 & 1.7 & 2.3 & 6.86 \\
\hline
\end{tabular}

Table 2: Estimated Regression Coefficients for Compressive strength (pseudo components)

\begin{tabular}{lrrrrr}
\hline Term & Coef & SE Coef & T & P & VIF \\
\hline Water & 2.4489 & 0.02978 & $*$ & $*$ & 1.608 \\
Cement & 1.8797 & 0.02978 & $*$ & $*$ & 1.608 \\
Quarry dust & 1.8500 & 0.02978 & $*$ & $*$ & 1.608 \\
Laterite & 2.1997 & 0.02978 & $*$ & $*$ & 1.608 \\
Water*Cement & 1.6791 & 0.17793 & 9.44 & 0.000 & 1.438 \\
Water*Quarry dust & 0.4207 & 0.17793 & 2.36 & 0.040 & 1.438 \\
Water*Laterite & 0.2791 & 0.17793 & 1.57 & 0.148 & 1.438 \\
Cement*Quarry dust & 2.7656 & 0.17793 & 15.54 & 0.000 & 1.438 \\
Cement*Laterite & 1.4239 & 0.17793 & 8.00 & 0.000 & 1.438 \\
Quarry dust*Laterite & 0.3256 & 0.17793 & 1.83 & 0.097 & 1.438 \\
\hline S $=0.0427451$ & PRESS $=0.152307$ & & & \\
R-Sq $=98.51 \%$ & R-Sq(pred) $=87.61 \%$ & R-Sq(adj) & $=97.17 \%$ \\
\hline
\end{tabular}

Table 3: Analysis of Variance for Compressive Strength (pseudo components)

\begin{tabular}{lrrrrrr}
\hline Source & DF & Seq SS & Adj SS & Adj MS & F & P \\
\hline Regression & 9 & 1.21058 & 1.210584 & 0.134509 & 73.62 & 0.000 \\
Linear & 3 & 0.41479 & 0.498662 & 0.166221 & 90.97 & 0.000 \\
Quadratic & 6 & 0.79579 & 0.795793 & 0.132632 & 72.59 & 0.000 \\
Water*Cement & 1 & 0.18407 & 0.162708 & 0.162708 & 89.05 & 0.000 \\
Water*Quarry d & 1 & 0.02135 & 0.010215 & 0.010215 & 5.59 & 0.040 \\
Water*Laterite & 1 & 0.01906 & 0.004495 & 0.004495 & 2.46 & 0.148 \\
Cement*Quarry d & 1 & 0.44759 & 0.441402 & 0.441402 & 241.58 & 0.000 \\
Cement*Laterite & 1 & 0.11761 & 0.117018 & 0.117018 & 64.04 & 0.000 \\
Quarry d*Laterite & 1 & 0.00612 & 0.006117 & 0.006117 & 3.35 & 0.097 \\
Residual Error & 10 & 0.01827 & 0.018271 & 0.001827 & & \\
Lack-of-Fit & 5 & 0.00657 & 0.006571 & 0.001314 & 0.56 & 0.729 \\
Pure Error & 5 & 0.01170 & 0.011700 & 0.002340 & & \\
Total & 19 & 1.22885 & & & & \\
\hline
\end{tabular}

Table 4: Estimated Regression Coefficients for water absorption (Scheffe's pseudo components) 


\begin{tabular}{|c|c|c|c|c|c|c|}
\hline \multicolumn{2}{|l|}{ Term } & Coef & SE Coef & $\mathrm{T}$ & $\mathrm{P}$ & VIF \\
\hline \multicolumn{2}{|l|}{ Water } & 8.55 & 0.3685 & * & * & 1.608 \\
\hline \multicolumn{2}{|l|}{ Cement } & 5.41 & 0.3685 & * & * & 1.608 \\
\hline \multicolumn{2}{|l|}{ Quarry dust } & 7.58 & 0.3685 & * & * & 1.608 \\
\hline \multicolumn{2}{|l|}{ Laterite } & 7.50 & 0.3685 & * & * & 1.608 \\
\hline \multicolumn{2}{|l|}{ Water*Cement } & -0.64 & 2.2012 & -0.29 & 0.777 & 1.438 \\
\hline \multicolumn{2}{|c|}{ Water*Quarry dust } & -12.96 & 2.2012 & -5.89 & 0.000 & 1.438 \\
\hline \multicolumn{2}{|c|}{ Water*Laterite } & -5.70 & 2.2012 & -2.59 & 0.027 & 1.438 \\
\hline \multicolumn{2}{|c|}{ Cement*Quarry dust } & 4.45 & 2.2012 & 2.02 & 0.071 & 1.438 \\
\hline \multicolumn{2}{|l|}{ Cement*Laterite } & 7.16 & 2.2012 & 3.25 & 0.009 & 1.438 \\
\hline \multicolumn{2}{|c|}{ Quarry dust*Laterite } & -0.33 & 2.2012 & -0.15 & 0.885 & 1.438 \\
\hline \multicolumn{7}{|c|}{$S=0.528812 \quad$ PRESS $=17.9427$} \\
\hline $\mathrm{R}-\mathrm{Sq}=86.92 \%$ & \multicolumn{3}{|c|}{$R-S q(p r e d)=16.06 \%$} & $\mathrm{R}-\mathrm{Sq}(\mathrm{ac}$ & $=75$ & $.14 \%$ \\
\hline
\end{tabular}

Table 5:Analysis of Variance for water absorption (Schefee's pseudo components)

\begin{tabular}{lrrrrrr}
\hline Source & DF & Seq SS & Adj SS & Adj MS & \multicolumn{1}{c}{ F } & P \\
\hline Regression & 9 & 18.5797 & 18.5797 & 2.06441 & 7.38 & 0.002 \\
Linear & 3 & 4.0461 & 10.8153 & 3.60510 & 12.89 & 0.001 \\
Quadratic & 6 & 14.5335 & 14.5335 & 2.42225 & 8.66 & 0.002 \\
Water*Cement & 1 & 0.0344 & 0.0237 & 0.02372 & 0.08 & 0.777 \\
Water*Quarry d & 1 & 8.7917 & 9.7007 & 9.70067 & 34.69 & 0.000 \\
Water*Laterite & 1 & 1.5638 & 1.8744 & 1.87435 & 6.70 & 0.027 \\
Cement*Quarry d & 1 & 1.1828 & 1.1441 & 1.14408 & 4.09 & 0.071 \\
Cement*Laterite & 1 & 2.9547 & 2.9573 & 2.95728 & 10.58 & 0.009 \\
Quarry d*Laterite & 1 & 0.0061 & 0.0061 & 0.00611 & 0.02 & 0.885 \\
Residual Error & 10 & 2.7964 & 2.7964 & 0.27964 & & \\
Lack-of-Fit & 5 & 0.7443 & 0.7443 & 0.14887 & 0.36 & 0.855 \\
Pure Error & 5 & 2.0521 & 2.0521 & 0.41042 & & \\
Total & 19 & 21.3761 & & & & \\
\hline
\end{tabular}

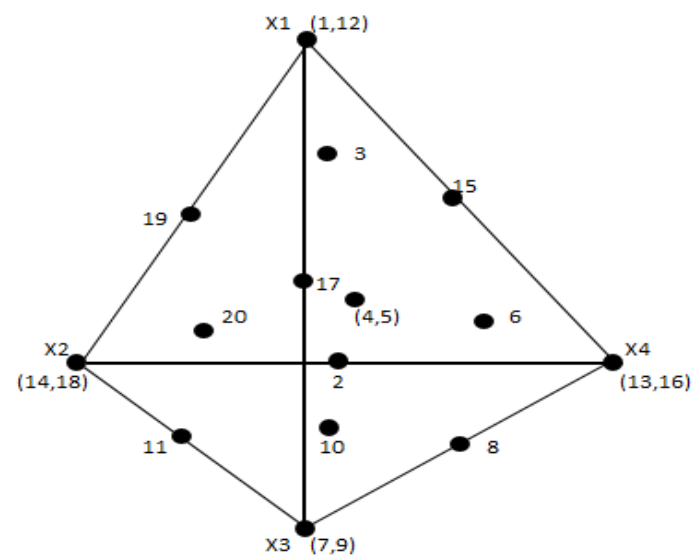

Fig 1: an augmented $\{4,2\}$ Simplex lattice showing the design points 


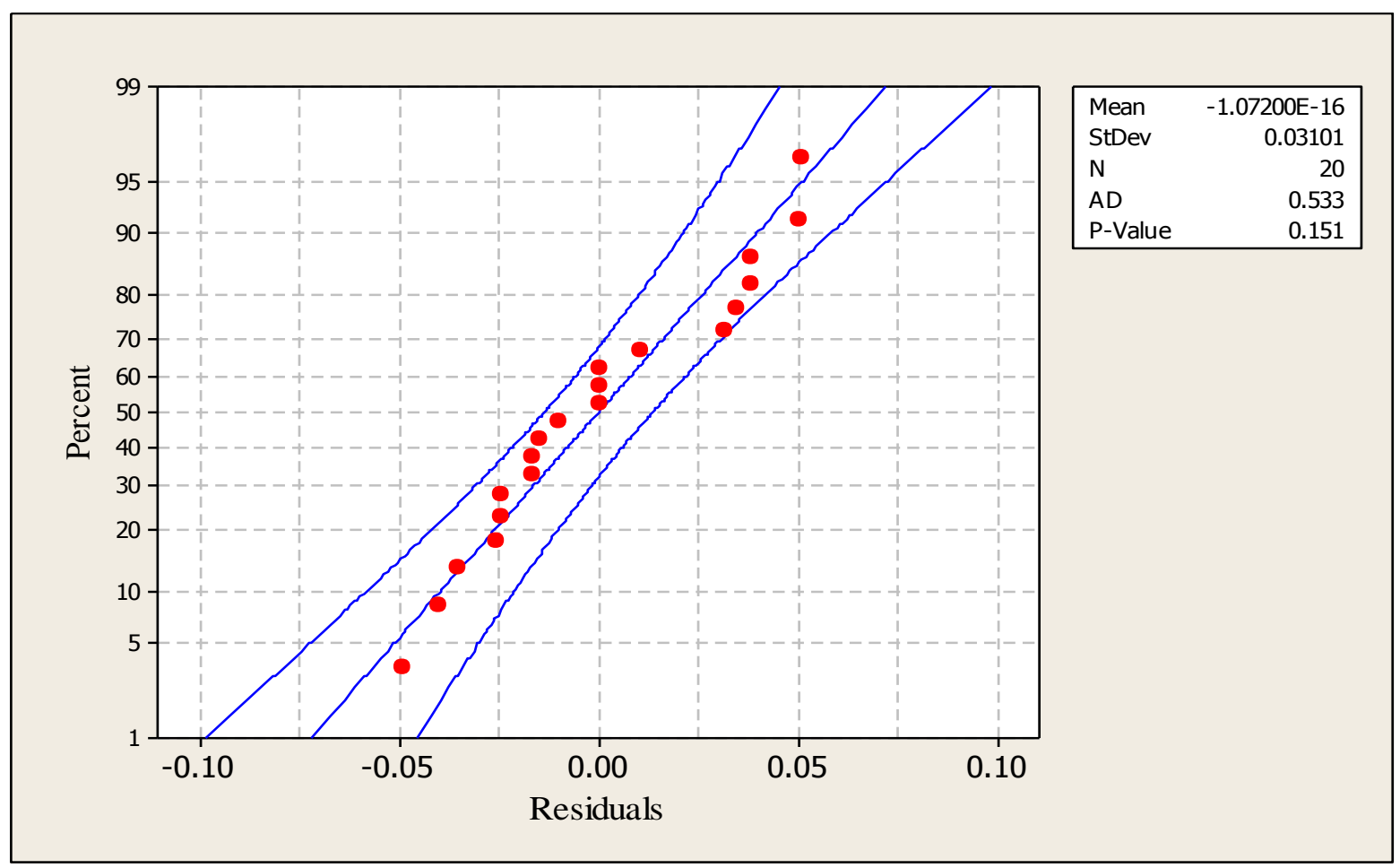

Fig 2: Normal probability plot for compressive strength residual (Scheffe's pseudo component model)

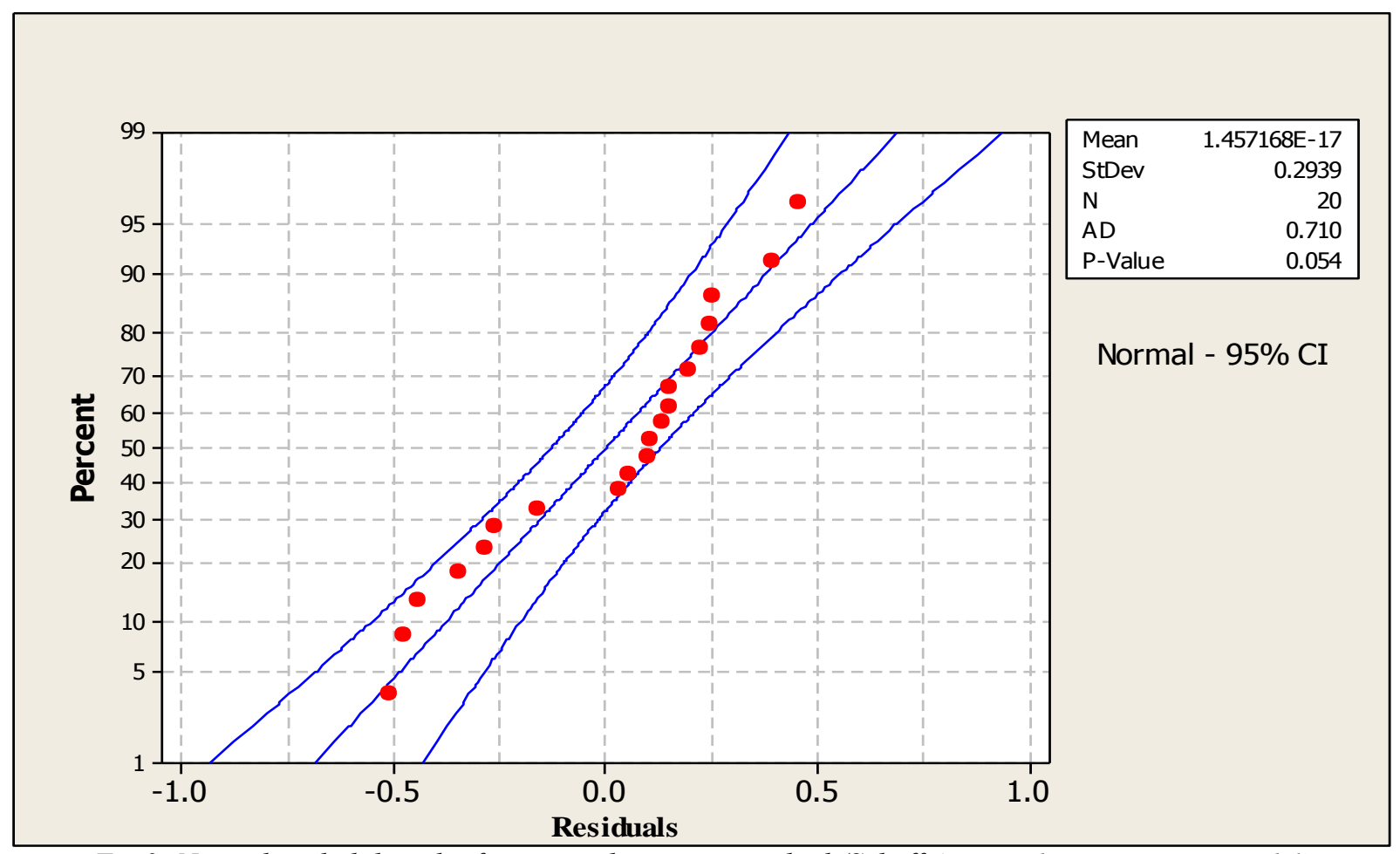

Fig 3: Normal probability plot for water absorption residual (Scheffe's pseudo components model)

\section{REFERENCES}

[1] Subramanian, K. and Kannan, A. "An experimental study on usage of quarry dust as partial replacement for sand in concrete and mortar". Australian Journal of Basic and Applied Science, 7 (8) , pp. 955-967. 2013.

[2] Asiedu, E. and Agbenyga, A. "Suitability of laterite fines as a partial replacement for sand in the production of sandcrete bricks. International
Journal of Emerging Technology and Advanced Engineering 4(10) pp 9-15 2014.

[3] Osuji, S. O. and Egbon, B. N. "Optimizing compressive strength characteristics of hollow building blocks from granite quarry dust and sand. Nigerian Journal of Technology Vol. 34(3), pp. 478483. 2015.

[4] Sureshchandra, H.S., Sarangapani, G. and Naresh Kumar, G. B. ("Experimental Investigation on the effect of Replacement of sand by quarry dust in 
Hollow concrete blocks for different mix proportions". International Journal of Environmental Science and Development Vol. 5, (1) pp. 15-19. 2014.

[5] Ukpata, J. O., Ephraim, E. M., and Akeke, G. A. "Compressive strength of concrete using lateritic sand and quarry dust as fine aggregate. ARPN Journal of Engineering and Applied science. Vol 7. (1) pp. 81-92, 2012.

[6] Ukpata, J. O. and Ephraim, E. M. "Flexual and Tensile strength properties of concrete using lateritic sand and quarry dust as fine aggregate". ARPN Journal of Engineering and Applied science. Vol. 7. (1) pp. 3243-331 2012.

[7] Cornell, J.Experiments with Mixtures: Designs, Models and the Analysis of Mixture Data. 3ed. John Wiley and Sons Inc. New York, 2002.

[8] Scheffe, H. "Experiments with mixtures". Journal of Royal Statistical Society, Series B. Vol. 20, No 2, pp. 344-360, 1958

[9] Osadebe, N. N., Onwuka, D. O. and Okere, C. E. "A model for optimization of compressive strength of sand- laterite blocks using Osadebe's Regression theory". International Journal of Engineering and Technical Research, Vol. 2. (1), pp. 83-87. 2014.

[10] Ezeh, J. C., Ibearugbulem, O. M. and Anya, U. C. "Optimization of aggregate composition of laterite/sand hollow block using Scheffe's simplex method". International Journal of Engineering, 4(4), pp. 471-478. 2010.

[11] Mama, B. O. and Osadebe, N. N. "Comparative analysis of two mathematical models for prediction of compressive strength of sandcrete blocks using alluvial deposit". Nigerian Journal of Technology, Vol. 30 No 3, pp. 82 - 89, 2011.

[12] Anyaogu, L., Chijioke, C. and Okoye, P. "Prediction of compressive strength of Pulverise fuel Ash-Cement concrete". IOSR Journal of Mechanical and Civil Engineering, Vol. 6, No. 1, pp. 01 - 09, 2013

[13] Anya, C. U. Models for predicting the structural characteristics of sand-quarry dust blocks. PhD

Thesis, School of Engineering, University of Nigeria, Nsukka, Nigeria, 2015.

[14] Simon, M. J. Concrete Mixture Optimization Using Statistical Methods: Final Report. FHWA Office of Infrastructure Research and Development, 6300, 2003.

[15] Wang, D. and Cheng, Z. " Predicting compressive strength of mortars with ternary blends of cement,
GGBFS and fly ash", Cement and Concrete Research, 27 (4), 1997,pp.487 - 493

[16] Akalin, O., Akay, K. U., Sennaroglu, B. and Tez, M., Optimization of chemical admixture for concrete on mortar performance tests using mixture experiments. 20 $0^{\text {th }}$ EURO Mini International Conference on Continuous Optimization and Knowledge- Based Technologies, pp.266 - 272, 2008.

[17] Obam, S. 0. "A mathematical model for optimization of Strength of concrete. A case for shear modulus of Rice husk ash concrete". Journal of Industrial Engineering International Vol. 5 (9), pp.76 - 84, 2009.

[18] Onwuka, D. O., Okere, C. E., Arimanwa, J. I. and Onwuka, S. U. "Prediction of concrete mix ratios using modified regression theory", Computational Method in Civil Engineering. Vol. 2, (1), pp 95 - 107. 2011.

[19] Osadebe, N. N. and Ibearugbulem, O. M. "Application of Scheffe's simplex model in optimizing compressive strength of periwinkle shell-granite concrete". The Heartland Engineer, Vol. 4 (1), (2009) pp.27 - 38.

[20] Ezeh, J. C. and Ibearugbulem, O. M. "Application of Scheffe's Model in Optimization of Compressive cube Strength of River Stone Aggregate Concrete". International Journal of Natural and Applied Science, 5(4), pp 303 - 308. 2009.

[21] Ezeh, J. C. and Ibearugbulem, 0. M. "Optimization of Compressive Strength of Recycled Aggregate Concrete Using Scheffe's Second degree Simplex Model". International Journal of Applied Engineering, Vol. 5(10), pp.1757 - 1764. 2010.

[22] Onuamah, P. N. and Osadebe, N. N. Development of Optimized strength model of lateritic hollow block with 4\% mould soil inclusion. Nigerian Journal of Technology, Nsukka, Nigeria. 34 (1), pp. 1-11, 2015.

[23] Minitab Inc. Minitab Statistical Software Release 16 Minitab Inc. State College Pennsylvania, 2010.

[24] British Standard Institution: BS EN 12390-4: Testing hardened concrete compressive strength, London , 2000.

[25] British Standard Institution, BS 1881-122 Testing concrete. Method for determining of water absorption. London, 1983.

[26] NIS 87, 2. Standard for sandcrete Blocks. The Nigerian Industrial Standard. Lagos, Nigeria: Standard Organization of Nigeria, 2000. 